\section{Response to: 'Domestic use of bleach and infections in children: a multicentre cross-sectional study'}

We write to express disappointment with the design flaws and speculative nature of the conclusions in the short report presenting findings from a study of domestic use of bleach and infections in children. ${ }^{1}$ The article concludes that "Passive exposure to cleaning bleach in the home may have adverse effects on school-age children's health by increasing the risk of respiratory and other infections. The high frequency of use of disinfecting irritant cleaning products may be of public health concern, also when exposure occurs during childhood."

Specific study design flaws include

- The study data rely on questionnaires completed by parents who were asked to differentiate between specific medical conditions (ie, influenza, tonsillitis, sinusitis, otitis and bronchitis). It is unclear if any information was provided to the parents regarding these conditions and how to diagnosis the conditions or if the diagnosis was confirmed by a physician.

- The high frequency of use of disinfecting irritant cleaning products may be of public health concern

- The study did not account for potential confounding factors that could influence the occurrence of infection in the children studied (ie, passive smoke, local air pollution, pre-existing health conditions).

- The questionnaire is limited by relying on a yes/no question regarding frequency of exposure to bleach. Specifically, parents were asked to respond yes/no regarding whether bleach was used to clean the home at least once per week. This yes/no response provides no information to help characterise the actual exposure or whether the bleach was used in appropriate quantities for cleaning or disinfection. It also does not take into consideration or request information on whether the child was present while the bleach was being used or specifically how the bleach was being used (ie, to disinfect household surfaces, toys, laundry).

- No information has been included to determine if other cleaning products were utilised in the home and, if they were, at what frequency they were used. This information could impact the conclusions of the report.
We hope that you will publish this letter so your readers can have a clear understanding of the design flaws associated with this study prior to applying the study conclusions more broadly. We would also request that the study authors provide a copy of the survey template as part of the supplemental materials for the article to improve transparency in the report.

\section{Kimberly Wise}

Correspondence to Dr Kimberly Wise, Chemical Products \& Technology Division, American Chemistry Council, Washington DC 20002, USA; kimberly_wise@ americanchemistry.com

\section{Competing interests None declared.}

Provenance and peer review Not commissioned; internally peer reviewed.

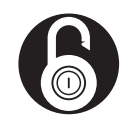

\section{OPEN ACCESS}

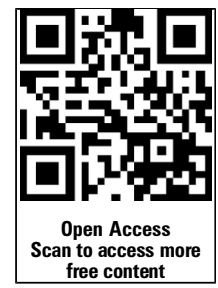

Open Access This is an Open Access article distributed in accordance with the Creative Commons Attribution Non Commercial (CC BY-NC 4.0) license, which permits others to distribute, remix, adapt, build upon this work non-commercially, and license their derivative works on different terms, provided the original work is properly cited and the use is noncommercial. See: http://creativecommons.org/licenses/ by-nc/4.0/

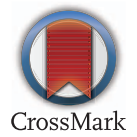

To cite Wise K. Occup Environ Med 2016;73:215.

Received 22 June 2015

Accepted 3 July 2015

Published Online First 2 February 2016

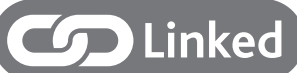

http://dx.doi.org/10.1136/oemed-2015-103255

Occup Environ Med 2016;73:215.

doi:10.1136/oemed-2015-103133

\section{REFERENCE}

1 Casas L, Espinosa A, Borràs-Santos $A$, et al. Domestic use of bleach and infections in children: a multicentre cross-sectional study. Occup Environ Med 2015;72: 602-4. 